\title{
Digital Literacy: A Survey Level Digital Literacy Competence among University Students in Jakarta
}

\author{
Diah Wardhani, Sri Hesti, Nindyta Aisyah Dwityas
}

Faculty of Communication Science, Universitas Mercu Buana, Jakarta, Indonesia

\begin{abstract}
Digital Literacy Competence is not yet mastered by the people of Indonesia. Understanding of reading material and the ability to produce positive reading has not been successfully implemented. The purpose of the study was to analyze the influence of parental roles on digital literacy competencies of the students of the Faculty of Communication Sciences, Universitas Mercu Buana. The concept of Interpersonal Communication by DeVito (2013) was used in this study. The role of the family can be classified into four, namely: (1) modeling; (2) mentoring; (3) organizing, and (4) teaching. Through survey methods and data analysis techniques with correlation and impact testing, the results of the study show that the role of parents has an influence on digital literacy competencies. The role of parents as models, mentors, organizers and instructors in educating and raising their children is highly recognized by their children. Meanwhile, the role of parents has not had a maximum effect on improving student literacy digital competencies.
\end{abstract} Keywords-The Role of Families, Digital Literacy Competence, Audiences.

\section{INTRODUCTION}

Indonesia has not mastered the six basic literacy established by the World Economic Forum in 2015. The six basic literacies are reading literacy, nu meracy literacy, scientific literacy, digital literacy, financial literacy, and also cultural and citizenship literacy (DeNard is \& Hackl, 2015). Forms of high literacy mastery are the ability to collaborate, critical thinking, creativity and communication skill(Briandana \& Dwityas, 2019). Those are the important aspects needed to win the global competition.

The low level of literacy which includes the ability to access, understand and use information appropriately is caused by low reading ability. The problem was also compounded by the low interest in reading. The UNESCO survey shows that the Indonesian people'sinterest of reading was only 0.001 percent. That is, in one thousand people there is only one person who has an interest in reading (Source: news from Indo Pos May 19, 2016).

The highly increasing number of internet users does not improve the digital literacy skills of the Indonesian people. According to Hiller Spiers, media literacy or digital literacy has three elements namely 1) finding and consuming digital content, 2) making digital content, and 3) communicating or sharing content (Education week, News Letter, Vol. 36, Issue 12, November 8, 2016, Pages 5-6).
Media literacy, information literacy and digital literacy are the three most prevailing concepts that focus on a critical approach towards media messages (Hobbs, 2010). A wareness of the growing importance of digital literacy in today's workplace coexists paradoxically with apparent foot-dragging on the part of many universities in assessment and amplification of these important competencies (Kahne, Lee, \& Feezell, 2012). This newly emerging concept of "digital literacy" may be utilized as a measure of the quality of learners' work in digital environments, and provide scholars and developers with a more effective means of communication in designing better user-oriented environments (Buckingham, 2008).

The purpose of this study is to reveal the digital literacy level of Indonesian university students specifically in one of the private university in Jakarta, the capital city of Indonesia. The results of this study can be used as input for the development of the higher education curriculum in Indonesia.

\section{CONCEPTUAL FRAMEWORK OF THE STUDY}

Literacy of Information and Communication Technology

Literacy of communication and communication technology according to Eu ropean Co mmunities (2007) is the basic ability in using digital devices to take, assess, store, produce, present, and exchange information, and to 
communicate and participate in collaborative networks through the Internet (Adeoye \& Adeoye, 2017).

According to Adeoye \& Adeoye (2017). Literacy of information and communication technology can be measured through several indicators, as follows: 1) Ability to use various digital devices to access information, 2) Ability to use various basic software such as Microsoft Office, 3) Ability to create images using online facilities, 4) Ability to produce music using online facilities, 5) Ability to produce videos using online facilities, 6) Knowledge of designing websites, 7) Knowledge of various types of licenses that apply to online content, 8) Confidence in displaying video content I made it online, 9) Knowledge of safe applications / software to download, 10) Ability to write comments on blogs, websites or forums, 11) Knowledge of information that can be shared online, 12) Carefulness in making comments online, 13) Be careful when interacting online, 14) Affection man How to protect privacy while doing activities online, 15) Ability to protect yourself when interacting online, 16) Ability to maintain ethics when communicating online, 17) Balance time for activities with and without digital devices.

\section{Media Literacy}

Media literacy is the ability to access, enjoy, interpret, analyze, produce, and evaluate messages in all varieties and combinations of print, visual and digital formats(Gilster, 1997). People who are media literate can use communication media to solve problems. They have critical understanding and information about how individuals and organizations build media messages. Through this understanding, media literate individuals can assess their own relationships with the media, and provide value and meaning to media use and media messages (Christ \& Potter, 1998).

Media literacy can be measured through several indicators, as follows: 1) Ability to use information from various media, 2) Ability to understand the purpose of messages presented by various media, 3) Ability to use devices (HP / tablet / laptop / computer, etc.) suitable for seeking information, 4) the ability to use the device (cellphone / tablet / laptop / computer, etc.) that is appropriate to use information, 5) the ability to use the device (cellphone / tablet / laptop / computer, etc.) that is appropriate for making information(Hobbs, 2017).

\section{Information Literacy}

Information literacy is a set of abilities that require individuals to recognize information with the ability to find, evaluate, and use effectively. In formation
Literacy is a transformation process where students need to find, understand, evaluate, and use information in various forms to create for personal, social or global purposes (Buckingham, 2008).

Information literacy can be measured through several indicators, as follows Adeoye \& Adeoye (2017): 1) The ability to identify the information needed. 2) Ability to choose trusted sources of information, 3) Ability to quickly get the information needed on the media, 4) Ability to distinguish genuine news or hoaxes, 5) Ability to distinguish news facts or opinions, 6) Ability to distinguish official sites or personal sites, 7) Ability to access various information needed on the media, 8) Ability to use various information obtained, 9) Ability to return information obtained to others, 10) Ability to bring together various information to be written back in their own language, 11 ) Ability to understand cata quotes online references using the correct format, 12) Ability to write reference sources obtained from the internet in the correct format.

\section{RESEARCH METHOD}

This is a descriptive study conducted to determine the value of independent variable, either one or more variables (independent) without making comparis ons or connecting with other variables (Vais hnavi \& Kuechler, 2015). Researchers use a quantitative approach with a survey method. Data collection is done by using research instruments as outlined in questionnaire. Survey method or survey research is research that takes samples from one population and uses a questionnaire as a basic data collection tool(Sugiyono, 2012).

\section{Population and Sample}

The population in this study were all active students of the Faculty of Communication Sciences, University of Mercu Buana batch 2018 totally 405 students. The reason for choosing the population is because the purpose of this study is to develop teaching methods in accordance with the characteristics of Faculty of Communication Science UMB Students. Sampling is done by using the Slovin pattern:

$$
\mathrm{n}=\frac{\mathrm{N}}{1+\mathrm{Ne}^{2}}
$$

$\mathrm{n}=$ number of sample

$\mathrm{N}=$ number of population

$\mathrm{e}=$ signification $(10 \%)$

$$
n=\frac{405}{1+405(0.05)^{2}}
$$


$\mathrm{n}=\mathbf{2 0 1}$

From the calculation it is known that the sample of this study was 201 students. The composition of the sample is taken proportionally based on the number of students in the four program of study in the Communication Science study program as follows:

Table.1: Sample Composition

\begin{tabular}{|c|c|c|c|}
\hline Faculty/Study Program & $\begin{array}{c}\text { Number of Active Students, } \\
\text { batch } \mathbf{2 0 1 8}\end{array}$ & $\begin{array}{c}\text { Number of } \\
\text { Sample }\end{array}$ \\
\hline Faculty of Communication Science & & & $\mathbf{5 \%}$ \\
\hline Broadcasting & 143 & 35 & 71 \\
\hline Public Relations & 153 & 38 & 76 \\
\hline $\begin{array}{c}\text { Advertising and Marketing } \\
\text { Communication }\end{array}$ & 62 & 15 & 31 \\
\hline Digital Communication & 47 & 12 & 23 \\
\hline
\end{tabular}

\section{Data Collecting Technique}

In this study, primary data was collected using a questionnaire. Secondary data is carried out through literature review.

\section{Operationalization of Concept}

There is one variable in this study, Dig ital Literacy Competence. This variable has three dimensions, namely:
(1) information and communication technology literacy (17 indicators); (2) media literacy (5 indicators), and (3) information literacy (12 indicators). The operationalization of the concept in this study can be seen in table 4.2 below:

Table.2: Operationalization of Concept

\begin{tabular}{|c|c|c|c|}
\hline Variabel & Dimention & Indicator & Scale \\
\hline $\begin{array}{l}\text { Digital } \\
\text { Literacy } \\
\text { Competence }\end{array}$ & $\begin{array}{l}\text { Information } \\
\text { and } \\
\text { Communicatio } \\
\text { n Technology } \\
\text { Literacy }\end{array}$ & $\begin{array}{l}\text { 1. The ability to use various digital devices to access } \\
\text { information }\end{array}$ & \multirow{14}{*}{$\begin{array}{l}\text { Likert } \\
\begin{array}{l}5=\text { Strongly } \\
\text { Agree }\end{array} \\
4=\text { Agree } \\
3=\text { Doubtful } \\
2=\text { Dis agree } \\
\text { 1=Strongly } \\
\text { Dis agree }\end{array}$} \\
\hline & & $\begin{array}{l}\text { 2. The ability to use various basic software such as } \\
\text { Microsoft Office }\end{array}$ & \\
\hline & & 3. The ability to make pictures using online facilities & \\
\hline & & 4. The ability to produce music using online facilities & \\
\hline & & 5. The ability to produce videos using online facilities & \\
\hline & & 6. Knowledge of designing websites & \\
\hline & & $\begin{array}{l}\text { 7. Knowledge of various types of licenses that apply } \\
\text { to online content }\end{array}$ & \\
\hline & & $\begin{array}{l}\text { 8. Confidence displays video content that I made } \\
\text { online }\end{array}$ & \\
\hline & & $\begin{array}{l}\text { 9. Knowledge of applications / software that is safe to } \\
\text { download }\end{array}$ & \\
\hline & & $\begin{array}{l}\text { 10. Ability to write comments on blogs, websites or } \\
\text { forums }\end{array}$ & \\
\hline & & $\begin{array}{l}\text { 11. Knowledge of information that can be shared } \\
\text { online }\end{array}$ & \\
\hline & & 12. Caution in making online comments & \\
\hline & & 13. Caution in online interactions & \\
\hline & & $\begin{array}{l}\text { 14. Understanding of how to protect privacy when } \\
\text { conducting activities online }\end{array}$ & \\
\hline
\end{tabular}




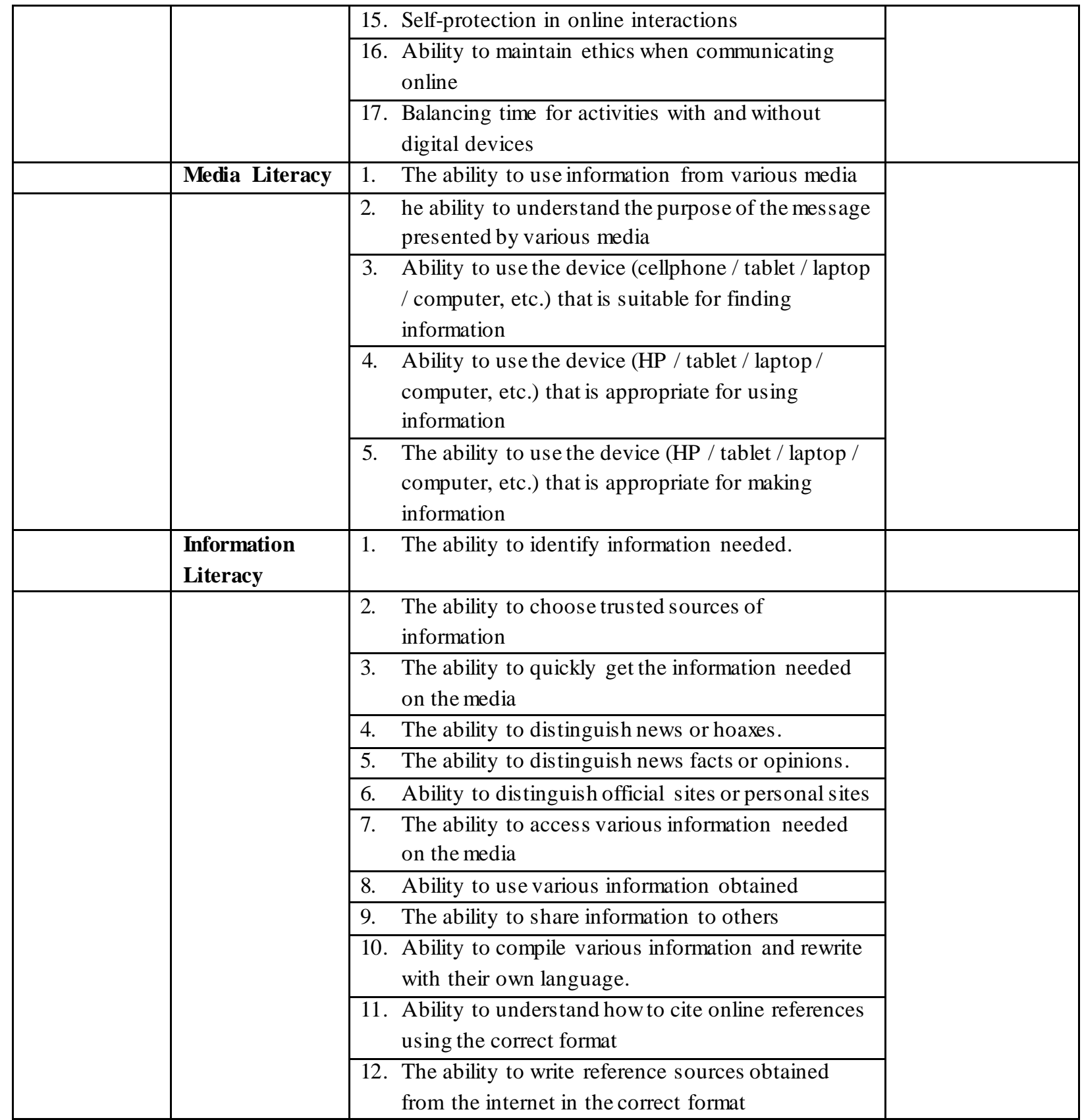

\section{Validity and Reliability}

The validity and reliability tests were carried out in two stages, firstly carried out to test the instruments in this study in the form of questionnaires, and both the validity and reliability tests for all questionnaires that had been filled in by the study sample.

Validity

Validity test is done by calculating the correlation between each statement with a total score using the "product moment" correlation technique formula. Data is processed using SPSS. The results are compared with the table values of the $r$ product moment values.
Reliability has various terms, such as reliability, reliability, discrepancy, consistency of the main ideas contained in the concept of reliability is the result of a reliable measurement. The measurement results can be trusted only if in several times the measurement of the same subject group obtained relatively the same results, as long as the aspects measured in the subject have not changed.

Instrument reliability testing in this study using Cronbach alpha. If the reliability value of questionnaire is $\alpha<0.60$ then the questionnaire is not reliable while if the questionnaire value $\alpha$ is $\geq 0.60$ then the questionnaire is reliable.

\section{Reliability}




\section{Data Analysis Technique}

The data analysis technique used in this study is descriptive data analysis techniques and inferential data analys is techniques.

In this study, the measurement scale used is the Likert scale $1 \mathrm{~d}$. 5. There is no transformation on the Likert scale because the Likert scale can be considered an interval (Ghozali, 2010). The questionnaire was asked to the same respondent, in fact the correlation value between the Likert scale and Gutman and Thotone correlation was 0.92. So the Likert scale can be considered an interval (Ghozali, 2010).

\section{Descriptive Analysis}

Descriptive analysis in this study was conducted to analyze respondents 'data as well as respondents' responses to research variables. Respondent data is presented in the form of a pie chart while for respondent responses will be presented as a percentage in the frequency distribution table.

\section{General Description of Research Subjects}

The research subjects were students of the Faculty of Communication Studies, Communication Studies Program, Field of Broadcasting Studies, Public Relations, Advertising and Marketing Communication and Digital Communication, University of Mercu Buana batch 2018. The age range of students is between $18 \mathrm{dd}$. 24 years old. Based on data from the Indonesian Generasi Milenian Profile book published by the Ministry of Women's Empowerment and Child Protection with the Central Bureau of Statistics in 2018, the age of research subjects falls into the millennial and generation $\mathrm{Z}$ categories. Millennials are those who were born between $1980 \mathrm{dd}$. 2000. While generation $Z$, they were born between 2001 and 2010. Both of these generations already know and have experience with gadgets, smartphones and other technological sophistication that are often referred to as generation of digital natives. The main characteristic of this generation is marked by increased use and familiarity with communication, media and digital technology(Wardhani, Hesti, \& Dwityas, 2019). This generation is a generation that involves technology in all aspects of life, including the process of learning in college.

\section{FINDINGS AND DISCUSSION}

\section{Instrument Testing}

In this study, instrument testing was carried out through validity and reliability tests on the variable level of digital literacy in two stages, namely the first stage was given to 30 (thirty) 2018 students of the Faculty of Communication Sciences. The second part of the test is the validity and reliability test conducted to test the instrument that has been filled in by the study sample, namely as many as 201 (two hundred and one) 2018 batch students of the Faculty of Communication Sciences.

\section{Validity and Reliability Test Part One}

The instrument of this study consisted of one variable, namely digital literacy competency as an independent variable with a number of 35 indicators.

\section{Validity Test}

This validity test is done for each item in the instrument. In this study, the validity test used is Pearson product moment correlation with two-way testing (two tailed test). The results of processing are compared with the table values of the $r$ product moment values. The number of $\mathrm{N}$ for this validity test is $30(\mathrm{df}=\mathrm{n}-2)$, so the $\mathrm{r}$ table value with a significant level of $5 \%$ is 0.361 with a significance level of $<0.05$. The total nu mber of indicators in testing the validity of digital literacy competency variables is 35 points but because 6 indicators are declared invalid, i.e. indicators with the codes "LTIK4, LTIK5, LTIK7, LI3, LI5, and LI13" with $\mathrm{r}$ product moment values smaller than 0.361 and the significance level is greater than 0.05 , the instrument is retested without including the indicators "LTIK4, LTIK5, LTIK7, LI3, LI5, and LI13". After the second test, which is on 29 indicators, there are still three invalid indicators, namely "LTIK8, LI7, and LI9", then retesting the instrument without including the indicators "LTIK8, LI7, and LI9". After the second test, all 26 indicators of digital literacy competency variables were declared valid.

\section{Reliability Test}

Reliability testing is done after all items in the instrument are declared valid. Instrument reliability testing in this study using Cronbach alpha. If the Cronbach alpha value is at least 0.6 , then the instrument is said to be reliable (Ghozali, 2005).

\section{Frequency Distribution}

Frequency distribution is carried out on the characteristics of respondents as well as indicators on each research variable, both media use, news needs and news satisfaction.

\section{Respondent Characteristics}

Characteristics of respondents, seen from the age of the respondent, the sex of the respondent, parental education, and the work of parents. 


\section{Age of Respondents}

Age of respondents ranged from 17 - 29 years. Of the 201 respondents, the majority of respondents were 64\% (129 students) aged 19-29 years. The Age Range is included in the millennial generation and the remaining $36 \%$ goes to generation $\mathrm{Z}$.

\section{Gender of Respondents}

The gender composition of the sample was not determined. The majority of respondents in the study $(61 \%)$ were women.

\section{Parents' Educational Backgrounds}

The majority of respondents parents education is primary to secondary education, which is primary to secondary education (elementary school until senior high school) of $60 \%$ and highly educated (Diploma in Masters) of $40 \%$.

\section{Parents' Job}

The majority of the respondent's fathers jobs were selfemployed and private employees, which amounted to $76.6 \%$. While the majority of mothers jobs are housewives, which is equal to $59.7 \%$ in this case, the majority of mothers have more time opportunities with children.

\section{DISCUSSION}

Nowdays, digital literacy competencies are very important for students. The development of communication and information technology makes eresources become one of the main learning resources. From the results of research conducted by Adiarsi, Stellarosa, \& Silaban (2015) it was found that digital literacy has a significant relationship with the quality of use of e-resources, in the very high correlation category, meaning digital literacy is a very decisive factor in the high quality of use of e-resources.

In Indonesia, the highest internet users are students, which is $89.7 \%$ (APJII, 2016). It is hoped that one of the priorities in the use of the internet by students is to support the learning process so that students are able to determine the information needed, access information effectively and efficiently, critically evaluate information, synthesize selected information into a knowledge base, use information effectively to resolve an assignment, understanding aspects of social, economic, legal issues that cover this information and using information ethically and legally (A merican Library of Association, 2000).

The results of this study, respondents' positive responses to aspects of digital literacy competency reached $67.9 \%$. A positive response to the competency aspect shows the ability of respondents regarding digital literacy. The highest presentation ability was in media literacy competency, namely $83.3 \%$, then communication and information technology literacy, which was $74.8 \%$ and the lowest percentage was information literacy competency which only reached $45.1 \%$.

Literacy of communication and information technology is the basic ability to use digital devices to take, assess, store, produce, present, and exchange information, and to communicate and participate in collaborative networks through the Internet (Adeoye \& Adeoye, 2017). In this case, the majority of the 2018 batch of Fikom UMB students already have these competencies. Competencies that still need to be improved are the ability to design websites, knowledge about software or applications that are safe to download, and the last is the ability to balance time in activities both with or without digital devices.

Regarding the time used by 2018 Fikom UMB students in their activities with and without gadgets, Rianto (2018) stated that children born in the digital age were referred to as the generation of digital natives, they did more activities using gadgets in their daily lives. These conditions need to be a concern of various parties including how universities can provide direction and debriefing to balance lifestyle better(Hobbs, 2011).

Furthermore, the results of the research on media literacy in this study the highest level of competence in students of the 2018 class of UMB showed that students have the ability to access, enjoy, interpret, analyze, produce, and evaluate messages in all varieties and combinations of print, visual, and and digital. What still needs to be improved in media literacy is the ability of students to understand the messages presented by various media.

The final dimension of digital literacy competencies, namely information literacy. Information Literacy itself is a transformation process in which students need to find, understand, evaluate, and use information in various forms to create for personal, social or global needs (Natharius, 2004). This ability is very important for students to support their learning process.

From the results of this study, information literacy competencies ranked the lowest compared to the dimensions of communication technology and information literacy and the dimensions of media literacy, which only reached $45.1 \%$. Things that still need to be improved by students related to information competence, especially in the ability to identify the information needed, the ability to choose reliable sources of information on digital media, the ability to distinguish 
original news or hoaxes, the ability to return information obtained to others, the ability to rewrite information obtained with their own language, as well as the ability to cite online references using the correct format.

Mercu Buana University students are a generation of digital natives where they learn quickly, process information quickly, although in the end they cannot concentrate properly, because they are looking for information quickly in a short time. This fast-paced generation tendency causes them to have more choice, without wanting to read the full information (Hobbs, 2017). This trend strengthens evidence of the low level of information literacy among these digital generation generations.

The role of various parties in improving student literacy competencies is very necessary. Universities in this regard as educational institutions that care for these students are expected to be more optimal to specifically equip students with digital literacy material. From the research findings, debriefing can focus on the main things such as: (1) the ability of students to understand the messages presented by various media; (2) the ability to identify the information needed; (3) the ability to choose trusted sources of information on digital media; (4) the ability to distinguish genuine news or hoaxes; (5) the ability to return information obtained to others; (6) the ability to rewrite information obtained in their own language; (7) the ability to cite online references using the correct format; (8) knowledge of software or applications that are safe to download; (9) ability to design websites; and the ability to balance time in activities both with and without digital devices.

Material about digital literacy can enter into the learning curriculum as well as through other special activities, whether it is included in the learning curriculum or with other special activities.

\section{CONCLUSION}

The conclusion of this study is that the positive response of the 2018 students of the Faculty of Communication, Mercu Buana University to aspects of digital literacy competence reached $67.9 \%$. This positive response shows the digital literacy ability of students. The ability with the highest presentation is in media literacy competence, which is $83.3 \%$, then the communication and information technology literacy, which is $74.8 \%$ and the lowest percentage is the information literacy competence which only reaches $45.1 \%$.

\section{SUGGESTION}

Based on the results, the student's digital literacy competencies not on the maximum level, especially in terms of information literacy. The tertiary party in this case as an educational institution that nurtures students is expected to be more optimal to specifically equip students with digital literacy material. From the findings of the research, debriefing can focus on key issues such as: (1) the ability of students to understand the messages presented by various media; (2) the ability to identify the information needed; (3) the ability to choose reliable information sources on digital media; (4) the ability to distinguish genuine news or hoaxes; (5) the ability to convey information back to others; (6) the ability to rewrite information obtained in their own language; (7) the ability to quote online references using the correct format; (8) knowledge of software or applications that are safe for download; (9) ability to design websites; and the ability to balance time in activities both with and without digital devices.

\section{REFERENCES}

[1] Adeoye, A. A., \& Adeoye, B. J. (2017). Digital Literacy Skills of Undergraduate Students in Nigeria Universities. Libr. Philos. Pract, 1665.

[2] Adiarsi, G. R., Stellarosa, Y., \& Silaban, M. W. (2015). Literasi media internet di kalangan mahasiswa. Humaniora, 6(4), 470-482.

[3] Briandana, R., \& Dwityas, N. A. (2019). Media literacy: An analysis of social media usage among millennials. International Journal of English Literature and Social Science, $\quad 4(2), \quad 488-496$. https://doi.org/10.22161/ijels.4.2.44

[4] Buckingham, D. (2008). What do young people need to know about digital media. Digital Literacies: Concepts, Policies and Practices, 73-88.

[5] Christ, W. G., \& Potter, W. J. (1998). Media literacy, media education, and the academy. Journal of Communication, 48(1), 5-15.

[6] DeNardis, L., \& Hackl, A. M. (2015). Internet governance by social media platforms. Telecommunications Policy, 39(9), 761-770.

[7] DeVito, J. A. (2013). Interpersonal Communication Book, The, 13/E. New York, NY: United.

[8] Gilster, P. (1997). Digital literacy. Wiley Computer Pub. New York.

[9] Hobbs, R. (2010). Digital and Media Literacy: A Plan of Action. A White Paper on the Digital and Media Literacy Recommendations of the Knight Commission on the Information Needs of Communities in a Democracy. ERIC.

[10] Hobbs, R. (2011). The state of media literacy: A response to Potter. Journal of Broadcasting \& Electronic Media, 55(3), 419-430.

[11] Hobbs, R. (2017). Measuring the digital and media 
literacy competencies of children and teens. In Cognitive development in digital contexts (pp. 253-274). Elsevier.

[12] Kahne, J., Lee, N.-J., \& Feezell, J. T. (2012). Digital media literacy education and online civic and political participation. International Journal of Communication, 6, 24.

[13] Natharius, D. (2004). The more we know, the more we see: The role of visuality in media literacy. American Behavioral Scientist, 48(2), 238-247.

[14] Rianto, P. (2018). Media Baru, Visi Khalayak Aktif dan Urgensi Literasi Media. Jurnal Komunikasi Ikatan Sarjana Komunikasi Indonesia, 1(2), 90-96.

[15] Sugiyono, M. (2012). Metode Penelitian Kuantitatif, Kualitatif, dan Kombinasi. Bandung: Alfabeta.

[16] Vaishnavi, V. K., \& Kuechler, W. (2015). Design science research methods and patterns: innovating information and communication technology. Crc Press.

[17] Wardhani, D., Hesti, S., \& Dwityas, N. A. (2019). Uses and Gratifications of Social Media: Media Use Among University Students in Jakarta. International Journal of Communication Reserach, 9(1), 23-31. 